\title{
FACTORS AFFECTING THE CONSULTATION SKILLS OF SOCIAL WORKERS WHEN SUPPORTING AUTISTIC CHILDREN'S FAMILIES: EVIDENCE IN VIETNAM
}

\author{
FACTORES QUE AFECTAN LAS HABILIDADES DE CONSULTA DE LOS \\ TRABAJADORES SOCIALES AL APOYAR A LAS FAMILIAS INFANTILES \\ AUTISTAS: PRUEBAS EN VIETNAM
}

\author{
Nguyen Hiep Thuong ${ }^{1}$ *; Kieu Van $\mathrm{Tu}^{2}$; Nguyen Van Hieu ${ }^{3}$. \\ 1. Hanoi National University of Education \\ No 136 Xuan Thuy street, Cau Giay district, Hanoi city, Vietnam \\ 2. Van Lang University \\ No 69/68 Dang Thuy Tram Street, Ward 13, Binh Thanh District, Ho Chi Minh City. \\ 3. Hanoi National University of Education \\ No 136 Xuan Thuy street, Cau Giay district, Hanoi city, Vietnam \\ *Correspondencia del Autor: Nguyen Hiep Thuong, correo electrónico: thuongnh@hnue.edu.vn.
}

\begin{abstract}
The research has identified the factors affecting the level of response to the job requirement of social workers when conducting counseling for families of children with autism in autism care and education centers. To achieve this goal, in this study we surveyed 89 social workers in Hanoi city. The results of the analysis of the multivariate linear regression model have shown that 6 factors have a significant impact on the level of response to the requirement of counseling skills when assisting autistic children's families, including (i) passion for work, (ii) professional knowledge and practical experience, (iii) proactive activeness, (iv) training opportunities to improve qualifications, (v) employment incentives, (vi) job requirements. The results showed that the passion for the job was most appreciated. On this basis, the study offers several meaningful solutions to improve the job response level of social workers when conducting counseling for autistic children's families.
\end{abstract}

Keywords: Counseling; counseling skills; autism; social workers.

Cómo citar:

Nguyen Hiep Thuong; Kieu Van Tu; Nguyen Van Hieu. (2021). FACTORS AFFECTING THE CONSULTATION SKILLS OF SOCIAL WORKERS WHEN SUPPORTING AUTISTIC CHILDREN'S FAMILIES: EVIDENCE IN VIETNAM. Revista de Investigaciones Universidad del Quindio, 33(1), 73-80. https://doi.org/10.33975/riuq.vol33n1.462

Información del artículo: Recibido: 6 abril 2021; Aceptado: 19 abril 2021

Revista de Investigaciones Universidad del Quindío, 33(1), 73-80; 2021.

ISSN: $1794-631 \mathrm{X}$ e-ISSN: 2500-5782 


\section{RESUMEN}

La investigación ha identificado los factores que afectan el nivel de respuesta a los requisitos laborales de los trabajadores sociales cuando realizan asesoramiento para familias de niños con autismo en centros de atención y educación. Para lograr este objetivo, en este estudio encuestamos a 89 trabajadores sociales en la ciudad de Hanoi. Los resultados del análisis del modelo de regresión lineal multivariante han demostrado que 6 factores tienen un impacto significativo en el nivel de respuesta al requerimiento de habilidades de consejería al ayudar a las familias de niños autistas, incluyendo (i) pasión por el trabajo, (ii) conocimiento profesional y experiencia práctica, (iii) actividad proactiva, (iv) oportunidades de capacitación para mejorar las calificaciones, (v) incentivos laborales, (vi) requisitos laborales. Los resultados mostraron que la pasión por el trabajo era muy apreciada. Sobre esta base, el estudio ofrece varias soluciones significativas para mejorar el nivel de respuesta laboral de los trabajadores sociales cuando realizan asesoramiento para las familias de niños autistas.

Palabras clave: Consejería; habilidades de consejería; autismo; trabajadores sociales.

\section{INTRODUCTION}

Social work is a professional activity aimed at assisting individuals, families, and communities to improve their capacities to meet their needs and strengthen social functions. It also enhances resources and services for individuals, families, and communities to address and prevent social problems to contribute to social security. A social worker is understood as someone who has been trained in social work. They use their knowledge and skills to provide social services to individuals, families, and communities facing difficult problems that they cannot solve. Social workers help them improve their capacity to deal with and solve problems, find the necessary resources, facilitate human-to-human interaction and human-to-environment interactions, promote social accountability, and influence social policies. In the process of helping difficult individuals and communities, social workers use many different roles and tasks. Counseling in general and counseling for families with autistic children, in particular, is one of the very important tasks of social workers. Families with autistic children are facing many difficulties withmaterial and mental crises.

\section{LITERATURE REVIEW}

The researches on professional counseling and counseling have appeared since the twentieth century. The contributors to the birth of consulting are Francis Galton, Wilhelm Wundt, James Catell, G. Parkley Hall, Alfred Binet, Jesse Davis, Frank Parson, Robert Yerkers [1].

Besides studies of personal counseling, career counseling, or counseling skills, researchers also find that when helping individuals, it is necessary to put themselves in the context, living and working environment of that individual. These research directions have approached human help in a broader social relationship rather than just confined to the individual as some of the therapeutic approaches mentioned above. Therefore, the research direction on family consultation is also interested in research by many researchers. These studies have complemented the ways an individual's thinking behavior interferes through impact to change the way family interactions. It is the power structure intervention model (strengths, boundaries, and connections in the family), structural and functional systems, communication modes in the family, or the 
model of social learning in the family like that of the authors: C. Allie Kilpatrick (1999) \& P. Thomas Holland (1993) [2], Ackerman and Satir, M.Bowen (1959), V.Satir, S. Minuchin [3] or Research by S. Slavson (1943, J. Moreno (1946), H.Ginott (1961), E. Jacbos (1988), G.Corey \& Correy (1992) .Eward E \& Reley L. (1992) Cappuzzi and Gross (1992). ) [4].

Author Hall, H.R. (2012) [5] in the autism family study "Families of children with autism: Behaviors of children, community support and coping" based on a study describing a crosssectional relationship with 38 parents with children with autism. Using the family behavior model by McCubbin and Patternson (1983) to analyze the relationship between the behavior of children with autism and community support for the family and the ability of the family to adapt/ resist. (28 mothers and 10 fathers).

\section{RESEARCH METHODS}

\section{- Model research}

The data is processed and analyzed by SPSS software.The averages, the percentage, the frequency is used to analyze the factors affecting the level of response to the job requirement of social workers when conducting counselingfor autistic child's family. Factors are identified through the Binary Logistic regression model, Cronbach Mart Alpha to analyze the correlation. The regression model is shown as follows:

$$
\begin{aligned}
& \operatorname{Ln}[\mathrm{p}(\mathrm{x}) / 1-\mathrm{p}(\mathrm{x})]=\beta 0+\beta 1 \mathrm{X} 1+\beta 2 \mathrm{X} 2+\beta 3 \mathrm{X} 3 \\
& +\beta 4 \mathrm{X} 4+\beta 5 \mathrm{X} 5+\beta 6 \mathrm{X} 6+\beta 7 \mathrm{X} 7+\ldots+\beta \mathrm{XXn} \\
& +\varepsilon
\end{aligned}
$$

Inside that:

The dependent variable $\mathrm{p}(\mathrm{x})$ is the degree of response to the consultation skills of the social worker when conducting counseling for families of children with autism, 0 and $1(0=$ impact and $1=$ no effect).

$\beta 0, \beta 1, \beta 2, \beta 3 \ldots . . \beta n$ is the regression coefficient to be estimated ( $\beta 0$ is the constant). $\varepsilon$ : is the error measuring the impact of variables not included in the model

\begin{tabular}{|c|c|}
\hline X1 - Passion for work & \\
\hline X2 - Professional knowledge and practical experience & skills of social \\
\hline X3 - Proactive activeness & workers when \\
\hline X4 - Training opportunities to improve qualifications & $\begin{array}{c}\text { supporting } \\
\text { autistic }\end{array}$ \\
\hline X5 - Employment incentives & children's \\
\hline X6 - Job requirements. & families \\
\hline
\end{tabular}

$\mathrm{X} 1, \mathrm{X} 2, \mathrm{X} 3, \ldots \mathrm{Xn}$ is independent variables included in the model explained:

Fig.1. Research model

(Source: Synthesis of the author)

\section{- Sampling method}

To achieve the study purpose, 89 representative samples, corresponding to 89 social workers working in autistic children's nurturing and education centers in Hanoi. The distribution of research objects in the practical survey is summarized in the following table: 
Table 1: Characteristics of research samples

\begin{tabular}{|l|l|c|c|}
\hline \multicolumn{2}{|c|}{ Criteria } & Number & \% \\
\hline \multirow{3}{*}{ 1. Gender } & Male & 19 & 21.3 \\
\cline { 2 - 4 } & Female & 70 & 78.7 \\
\hline \multirow{4}{*}{ 3.Qualification } & $21-30$ & 64 & 71.9 \\
\cline { 2 - 4 } & $31-40$ & 23 & 25.8 \\
\cline { 2 - 4 } & Over 40 & 2 & 2.2 \\
\hline \multirow{4}{*}{ 4.Years of experience } & Intermediate degree & 1 & 1.1 \\
\cline { 2 - 4 } & College degree & 18 & 20.2 \\
\cline { 2 - 4 } & Bachelor's degree & 55 & 61.8 \\
\cline { 2 - 4 } & Master's degree & 15 & 16.9 \\
\hline \multirow{3}{*}{$\begin{array}{l}\text { 5.Yearsofexperience as a } \\
\text { consultant }\end{array}$} & $1-5$ & 60 & 67.4 \\
\cline { 2 - 4 } & $6-10$ & 17 & 19.1 \\
\cline { 2 - 4 } & Over 10 & 12 & 13.5 \\
\cline { 2 - 4 } & $1-5$ & 79 & 88.8 \\
\cline { 2 - 4 } & $6-10$ & 10 & 62.9 \\
\cline { 2 - 4 } & Community service & 56 & 23.6 \\
\cline { 2 - 4 } & Psychology & 21 & 5.6 \\
\cline { 2 - 4 } & Special education & 7 & 7.9 \\
\cline { 2 - 4 } & Other & 5 & 11.2 \\
\hline
\end{tabular}

\section{- Data collection methods}

(i) In-depth interview, 22 social workers working in Hanoi to collect their opinions on the factors affecting counseling skills for families of children with autism.

(ii) The scale used in this study is Likert to measure the survey questions with the following convention: (Level 4): completely correct; (Level 3): mostly true; (Level 2): mostly false; (Level1): completely wrong

(iii) After data collection, SPSS 22.0 is used to analyze the factors affecting the response to the consultation skills of social workers. In particular, Cronbach Mart Alpha is used to evaluate the reliability of the variables; Exploratory factor analysis (EFA) to find the factor that strongly affects the model, variance inflation factor (VIF) and Tolerance is used to check the validity of the research model.

\section{RESULTS AND DISCUSSION}

\section{Correlation between counseling skill for autistic children's families of social workers with subjective factors}

We found that counseling skills for autistic children's families of social workers were most closely correlated with passion, interest in work $(r=0.656$ and $\mathrm{p}<0.01)$. Social workers, always passionate and enthusiastic while working, often find their work attractive and always try their best to achieve their goals. When they have such aspirations, they will always explore and learn constantly to develop 
their career path. Lack of passion for the job will make their counseling skills not fulfill their potential.

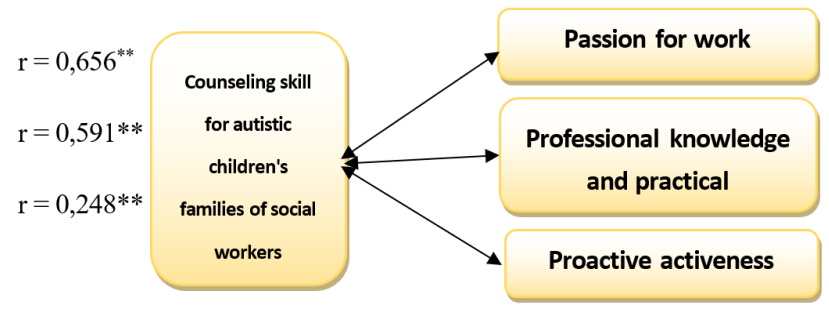

Diagram 1: Correlation between counseling skill for autistic children's families of social workers with subjective factors

Note: On the diagram, the correlation coefficients are statistically significant with $\mathrm{r} * *$ when $\mathrm{P}<0.01$ and $\mathrm{r}$ is the Pearson correlation coefficient

The statistical results also show that the positive correlation has a statistical meaning between consultation skills and the factor "Professional knowledge and practical experience" with $\mathrm{r}=$ $0.591 ; \mathrm{P}<0.01$. Without specialized knowledge and practical experience, social workers will have difficulty in implementing counseling skills for families with children with autism.

The co-variation of consultation skills of social workers withproactive activeness has the correlation coefficient $\mathrm{r}=0.248$ and $\mathrm{p}<0.01$. When social workers are always active at work, believe in their efforts rather than luck, always be ready and respond to unplanned changes, implementation of the counseling skills for autistic children's families of social workers will become effective and can bring the desired results. The proactive activenessaffects the quality of consultation of each social worker.

In summary, the consultation skills with subjective factors are positively and quite closely correlated. The relationship between consultation skills with passion for workof social workers has the closest connection. When social workers are interested in counseling, they will try their best to improve their knowledge, accumulate experience, thereby supplement the gaps, gradually improve their knowledge and skills to well perform counseling skills in autistic children's family.

\section{Correlation between the counseling skills for families of social workers with autism and the objective factors}

Statistical results show that there is a statistically significant correlation between counseling skills and objective factors, including training opportunities to improve qualifications, employment incentives, job requirements.

However, this positive correlation is less closely linked than that between counseling skills and the above subjective factors. It is easy to see that social workers' counseling skills are most closely correlated with training opportunities to improve qualifications $(r=0.371$ and $p<0.01)$. This proves that training courses to improve professional qualifications, conferences to exchange knowledge and experiences, and consultation classes conducted by domestic and foreign experts have facilitated counseling. These social workers' skills are developing to their full potential. On the contrary, social workers' counseling skills will be hampered if they are not given opportunities to improve their qualifications.

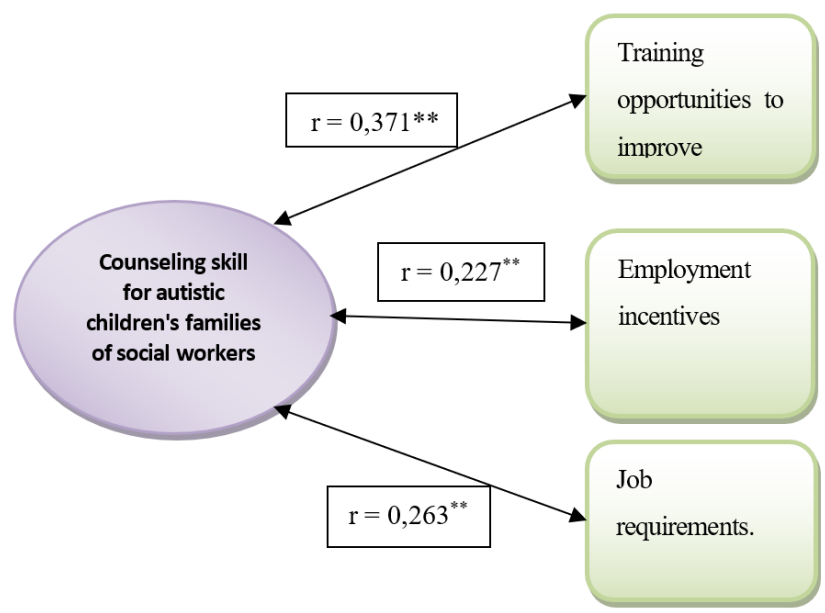

Diagram 2: Correlation between counseling skill for autistic children's families of social workers with objective factors

Note: On the diagram, the correlation coefficients are statistically significant with $\mathrm{r} * *$ when $\mathrm{P}<0.01$ and $\mathrm{r}$ is the Pearson correlation coefficient. 
Counseling skills of social workers also correlated positively but less closely with two objective factors: employment incentives, job requirementswith $r$, respectively: $0.227 ; 0.263$ and $p<0.01$. This shows that the higher the job requirements, the more proficient the social workers are in counseling skills. That means the more professional skills the job requires, the more knowledge that is related to many fields, the more social workers have to constantly try to develop themselves. Similarly, if social workers are motivated, praised, rewarded with different forms of hard work, and properly punished for not completing their tasks, they will try their best in their job.

The above analysis shows that objective factors such as training opportunities to improve qualifications, employment incentives, job requirements affect social workers' counseling skills for autistic children'sfamilies. Among these three impact factors, training opportunity to improve qualificationsis the objective factor that has a stronger impact on the counseling skills of these research subjects. Being aware of the influence of these objective factors will help social workers more favorable in training and implementing counseling skills for autistic children's families.

\section{Predict the level of counseling skills for families of children with autism of social workers when the influencing factors change}

The first-order regression analysis allows predicting the change in EL of children affected by HIV / AIDS from the changes of every single independent factor as well as a combination of subjective factors and factors. objective.

- Predict the level of counseling skills for families of children with autism under the influence of each single independent factor

Understanding the factors influencing the counseling skills for autistic children's families of social workers provides important information in proposing several measures to improve the accuracy, proficiency and flexibility of counseling skills of social workers. First, we will look at the predictability of each independent factor to find the dominant role of factors considered to be important. Second, consider the forecasting counseling skills of each group of factors to see the predictive capacity of each of these groups of factors.

The results are shown in Table 3.21 shows that both subjective and objective independent factors all influence the counseling skills of social workers for autistic children's families.In particular, passion for work (one of the subjective factors) and training opportunities to improve qualifications (one of theobjective factors) is considered the strongest influence $(\mathrm{R} 2=0,401$ and 0.138 with $\mathrm{P}<0.001$ ). This means that letting social workers perform well on counseling skills depends greatly on their passion for their career as well as their professional qualifications. When social workers are enthusiastic, dedicated to their work and given conditions to participate in training to improve their qualifications, they will better perform counseling skills for families with children with autism.

Professional knowledge and practical experience is the second most predictable subjective factors. This factor can explain $33.2 \%$ of the change in counseling skills of social workers for autistic children's families $(\mathrm{P}<0.001)$. The training, equipping with knowledge about counseling skills, and being more involved in professional activities to accumulate practical experience have a great impact on the level of counseling skills implementation of social workers. If social workersare interested in the job and have training opportunities to improve professional knowledge, practical experience, social workers' counseling skills will be improved. 
Table 2: Predict the level of counseling skills for families of children with autism under the influence of each single independent factor

\begin{tabular}{|c|c|}
\hline Independent variables & $\begin{array}{c}\text { Dependent variable } \\
\text {-Counseling } \\
\text { skillsofsocial } \\
\text { workers }\left(\mathbf{r}^{2}\right)\end{array}$ \\
\hline 1. Passion for work & $0.401^{* * *}$ \\
\hline $\begin{array}{l}\text { 2. Professional knowledge } \\
\text { and practical experience }\end{array}$ & $0.332^{* * *}$ \\
\hline 3. Proactive activeness & $0.057^{* * *}$ \\
\hline $\begin{array}{l}\text { 4. Training opportunities } \\
\text { to improve qualifications }\end{array}$ & $0.138^{* * *}$ \\
\hline 5. Employment incentives & $0.052^{* * *}$ \\
\hline 6. Job requirements & $0.069^{* * *}$ \\
\hline
\end{tabular}

The data in Table 2 show that counseling skills for autistic children's families of social workers are also influenced by the subjective factor of " proactive activeness" (the predictive ability of this factor is $5.7 \%$ with $\mathrm{P}<0.001$ ). Besided, counseling skills are also influenced by objective factors, which are "work incentives" (the predictive ability of this factor is $5.2 \%$ with $\mathrm{P}$ $<0.001$ ) and " job requirements" (the predictive ability of this factor is $6.9 \%$ with $\mathrm{P}<0.001$ ).

Thus, of the three subjective factors affecting the counseling skills of social workers, we find that passion, passion in work is the most subjective factor affecting the most. Among the three objective impact factors considered in this study, training opportunities to improve qualifications is the most influential factor affecting the counseling skills of social workers.

- Predict the level of counseling skills for families with autistic children under the impact of the cluster of factors

All the cluster factors considered here are capable of predicting counseling skills for autistic children's families of social workers. However, the predictive level of the cluster of factors for counseling skills of these social workers is not quite the same. There are factor clusters that explain only a small part, but there are also factor clusters that explain a greater proportion of the counseling skills for autistic children's families of social workers.

Table 3: Projected changes in counseling skills for autistic children's families of social workers under the impact of cluster of factors

\begin{tabular}{|l|l|}
\hline Groups of independent variables & $\begin{array}{l}\text { Dependent } \\
\text { v a r i a b l e : } \\
\text { Counseling } \\
\text { skills }\left(\mathrm{r}^{2}\right)\end{array}$ \\
\hline $\begin{array}{l}\text { 1.Subjective factors (Passion in } \\
\text { job }+ \text { Professional knowledge } \\
\text { trained and practical experience } \\
+ \text { Proactiveactiveness) }\end{array}$ & $0.470^{* * *}$ \\
\hline $\begin{array}{l}\text { 2.Objective factors (Training } \\
\text { opportunities to improve } \\
\text { qualifications + Employment } \\
\text { incentives+ Job requirements) }\end{array}$ & $0.215^{* * *}$ \\
\hline $\begin{array}{l}\text { 3. Subjective factors + objective } \\
\text { factors }\end{array}$ & $0.503^{* * *}$ \\
\hline
\end{tabular}

Note: $r 2$ - First order regression coefficient $* * *$ when $P$ $<0.001$; The statistically significant values are displayed on the table only

The rate of explanation for the variation of the dependent variable of the factor clusters over the coefficient R2 is not the same. Thereby, we see that the highest level of prediction belongs to the cluster that synthesizes all the subjective and objective factors. This group explains 50.3\% of counseling skills. This means that when social workers meet all 6 factors, both objective and subjective (including professional knowledge and practical experience, passion for work, proactive activeness, training opportunities to improve qualifications, employment incentives, job requirements), they will have counseling skills with high precise, proficient and flexible level.

The second most predictable factor cluster is the subjective factor cluster, including professional knowledge and practical experience, passion for work, proactive activeness. This cluster of factors can predict $47.0 \%$ for counseling skills of social 
workers when consulting with autistic children's families.

Cluster of objective factors has the lowest predictive ability with a forecast of up to $21.5 \%$ for counseling skills of social workers. This means that when social workers are allowed to improve their qualifications, are encouraged to work together with the strict requirements of knowledge, qualifications and skills of the job, the implementation is correct. The basic and specialized counseling skills of social workers are also enhanced with proficiency and flexibility when consulting with autistic children's families.

\section{CONCLUSIONS RECOMMENDATIONS}

AND

In summary, the combination of subjective and objective factors was the highest probability for predicting counseling skills for autistic children's families of social workerscompared to the set of other factors and the higher each factor individually. When social workers are passionate about their jobs, try their best to forget about their professional activities, have professional knowledge and practical experience, they are always proactive at work, at the same time, are trained to improve their qualifications, are encouragedwhen working effectively, be under the pressure of high professional qualifications, the counseling skills of social workers will be improved day by day. On this basis, we give some recommendations for social workers when conducting counseling for families of children with autism in the future as follows:

(i) Social workers are aware of the mission and value of the social work profession to the disadvantaged group andsociety. Must be selfmotivated in actively seeking information, selftraining and fostering to improve professional qualifications to help autistic children's families become more and more effective, thereby, asserting the role of social workers in connecting supporting resources with disadvantaged groups in general and autistic children's families in particular.

(ii) Social workers need to have passion, interest, enthusiasm for their consulting work and are always ready to participate in their professional development activities.

(iii) Special education centers, where social workers are working, need to create opportunities for social workers to be trained and fostered to improve their professional skills, such as creating conditions for social workers to participate in the short term and long termcourses; to participate in training courses to improve professional qualifications, participate in conferences, seminars to exchange knowledge and experience about counseling for autistic children's families, participate in counseling classes taught by domestic and foreign experts.

(iv) Facilities and centers with autistic children, where social workers are working, need to motivate, praise, and reward them materially when social workers work actively, effectively and properly penalize when they do not complete their tasks. This will encourage social workers to actively work and their counseling skills will be developed and improved.

\section{REFERENCES}

1. Tran Thi Minh Duc (2003), Consultation situation in Vietnam: from theory to practice, Journal of Psychology, (No. 2), pp.10-16.

2. Allie C. Kalpaltrick, Thomas P. Holland, Family Social Work (translated by Nguyen Xuan Huong) (2008), Hanoi

3. Salvador Minuchin \& H. Charles Fishman (1981), Family Therapy Techniques. Harvard University Press.

4. Cappuzzi D \& Grossi D.R. (1992), Group Counseling Theories and Application Introduction to Group Counseling, Love Publishing Company

5. Hall, H.R (2012), Families of children with autism: Behaviors of children, community support and coping. Issues in comprehensive pediatric nursing, 35 (2), pp 111-132. 